\title{
$N$-Heterocyclic Carbene Catalysis under Oxidizing Conditions
}

\author{
Krzysztof Dzieszkowski ${ }^{(D)}$ and Zbigniew Rafiński *(D) \\ Faculty of Chemistry, Nicolaus Copernicus University in Toruń, Gagarin Street 7, 87-100 Toruń, Poland; \\ dzieszko@doktorant.umk.pl \\ * Correspondence: payudo@chem.umk.pl; Tel.: +48-56-611-4530
}

Received: 17 October 2018; Accepted: 14 November 2018; Published: 16 November 2018

\begin{abstract}
N$-heterocyclic carbene organocatalysis under oxidizing conditions provides a vast range of various synthetic procedures via diverse mechanisms. The available catalysts, bases, oxidants, and oxidizing methods afford numerous opportunities for developing this branch of organocatalysis. Furthermore, implementation of tandem reactions and cooperative catalysis in the described methodology significantly expands the possibilities of modern organic chemistry. This approach allows the synthesis of different structurally complex and often enantiomerically enriched substances, which can be interesting in terms of biological activity and natural product synthesis. Many esters, amides, thioesters, lactams, lactones, and other cyclic compounds obtained in oxidative or oxygenative reactions promoted by $\mathrm{N}$-heterocyclic carbenes can be interesting precursors in advanced organic synthesis. Sophistication and broad applicability prove that the described synthetic approaches are exceptionally worthy of further development.
\end{abstract}

Keywords: $\mathrm{N}$-heterocyclic carbenes; oxidations; Breslow intermediate; acylazolium; catalysis

\section{Introduction}

$\mathrm{N}$-heterocyclic carbene (NHCs) catalysis is constantly developing as a diverse strategy for the synthesis of complex organic molecules. NHC-catalyzed reactions enable the formation of many carbon-carbon and carbon-heteroatom bonds, including heterocyclic rings [1-8]. N-heterocyclic carbenes were originally applied in umpolung benzoin condensation [9], which is still the most examined NHC-catalyzed reaction model [10]. In this type of reaction, a Breslow intermediate is generated after the nucleophilic attack of carbene on a carbonyl carbon atom. Moreover, this intermediate exhibits nucleophilic properties, in contrast to carbonyl compounds which are typically electrophilic agents (Figure 1) [11].

Unique $\alpha, \beta$-unsaturated acylazoliums can also be generated by the reaction of NHCs with $\alpha, \beta$-unsaturated enol esters or ethers [12-14], acyl fluorides [15,16], ynals [17-20], or 2-bromoenals [21-24]. In contrast to the nucleophilic Breslow intermediate, the aforementioned acylazoliums exhibit electrophilic properties. Furthermore, the Breslow intermediate can be oxidized to acylazolium, which is a very useful acylium cation synthon. Consequently, among other protocols, oxidative NHC catalysis is a unique method for the synthesis of amides and esters [25-29].

This review contains examples of a broad range of oxygenative or oxidative NHC-catalyzed reactions, which are crucial for modern organic synthesis. The article is focused on the application of NHC catalysis under oxidizing conditions, as an example of cooperative catalysis with the use of an external oxidant [30]. The aim of this work is also the nomenclature overview of this significant and relevant synthetic approach, and a breakdown by oxidation path. Moreover, this review is aimed at updating the status of NHC-catalyzed reactions under oxidizing conditions in existing review papers [31,32]. 


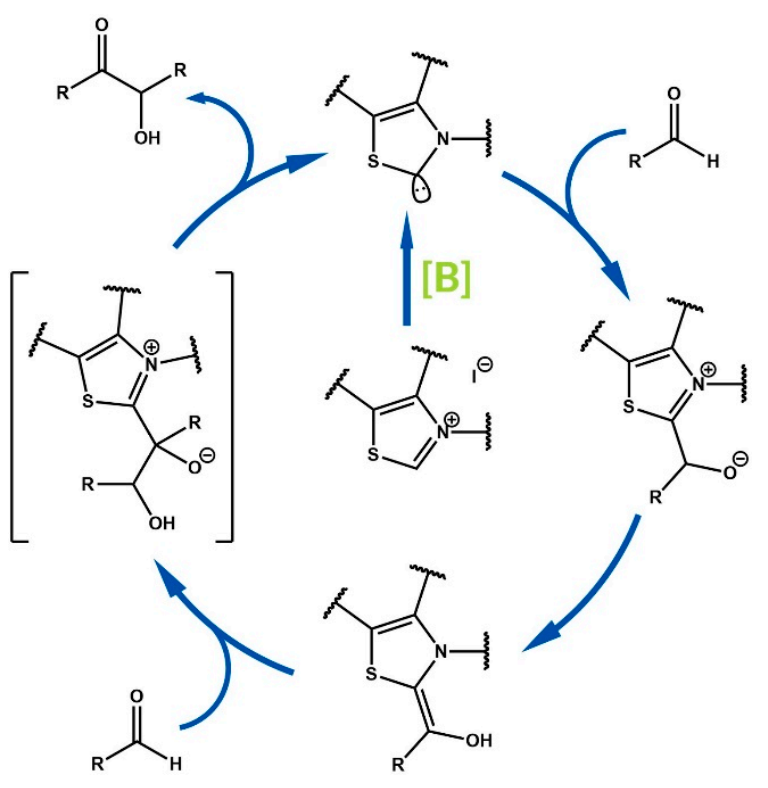

Figure 1. Benzoin condensation mechanism.

\section{Mechanistic and Nomenclature Issues}

Oxidative NHC catalysis, similarly to the classical umpolung process, is initiated by the Breslow intermediate, which is generated from a $N$-heterocyclic carbene and carbonyl compound-typically aldehyde. An acylazolium ion, which is electrophilic acylium cation synthon, is formed via transfer of two electrons from the mentioned intermediate to the oxidant in the reaction mixture. The nucleophile added as a reactant undergoes nucleophilic substitution to the carbonyl group of the acylazolium ion, with subsequent elimination of the azolium cation and regeneration of the catalyst (Figure 2) [31].

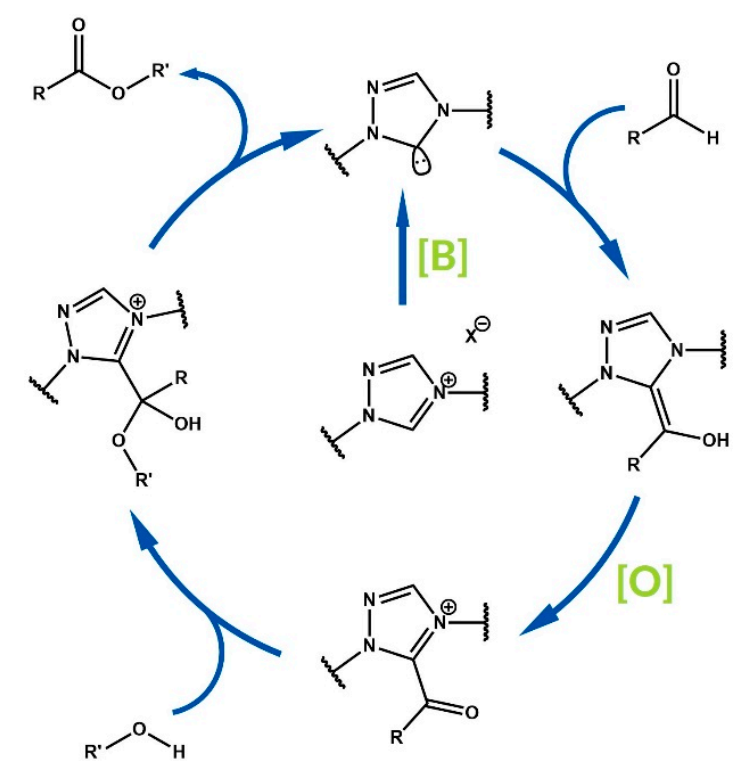

Figure 2. Mechanism of oxidative NHC-catalyzed esterification.

On the other hand, the Breslow intermediate can be oxidized via oxygen atom transfer from an oxidizing agent. After formation of a peroxide zwitterion, a second molecule of aldehyde is oxidized by the peroxide species, then the azolium intermediate is eliminated and the carboxylate ion is formed. Next, the obtained carboxylate participate in the reaction with an electrophile is added to the reaction mixture. This path is called oxygenative NHC catalysis, in contrast to the oxidative path (Figure 3). In oxygenative carboxylations, molecular oxygen can be used as external oxidant. In the 
case of spin-allowed oxygenation with $\mathrm{O}_{2}$, the reaction occurs via the single-electron-transfer (SET) process [33]. Some mechanisms assume that intermediate dioxetane species can be involved [34].

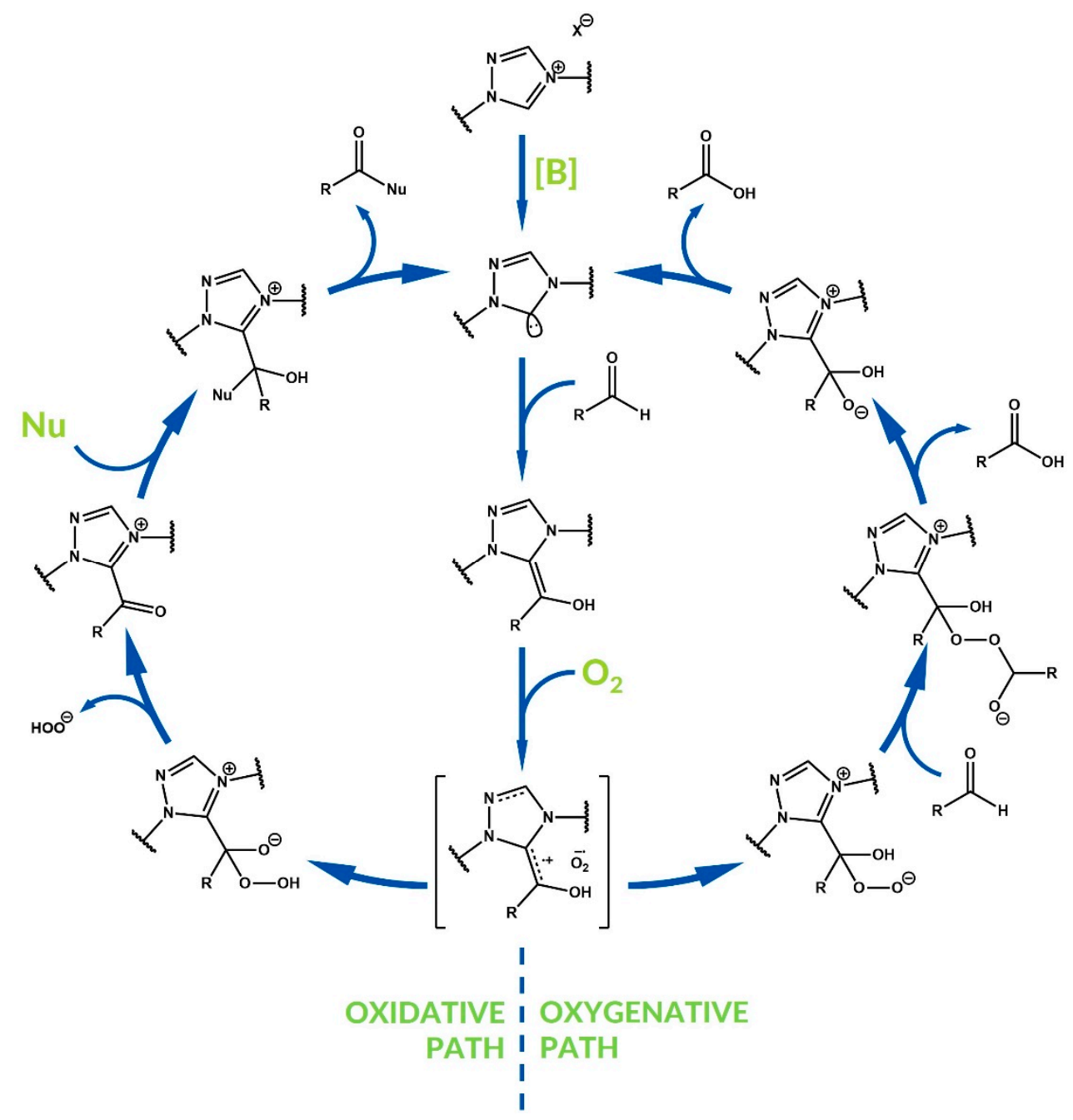

Figure 3. Difference between oxidative and oxygenative NHC catalysis using oxygen as an oxidant.

Moreover, the oxygenative path is not the only possible reaction mechanism in the case of using molecular oxygen as an oxidant. An acylazolium ion can be formed after elimination of a hydroperoxyl anion from the peroxide zwitterion. This path is also oxidative NHC catalysis, because an acylazolium intermediate is generated [33].

\section{Oxygenative NHC Catalysis}

Oxygenative NHC catalysis was first reported by Deng's group in 2010 (Figure 4a) [35]. Benzyl benzoate derivatives were obtained with good yields in the reaction of benzaldehydes with benzyl bromides under aerobic conditions, using a thiazolium catalyst. Similar syntheses were described one year later by Liu et al. [36]. They involved reactions between cinnamaldehydes and cinnamyl bromides or allyl bromides using a benzimidazolium catalyst (Figure 4b). Moreover, the authors used as an oxidant not only molecular oxygen, but also manganese(IV) oxide. 


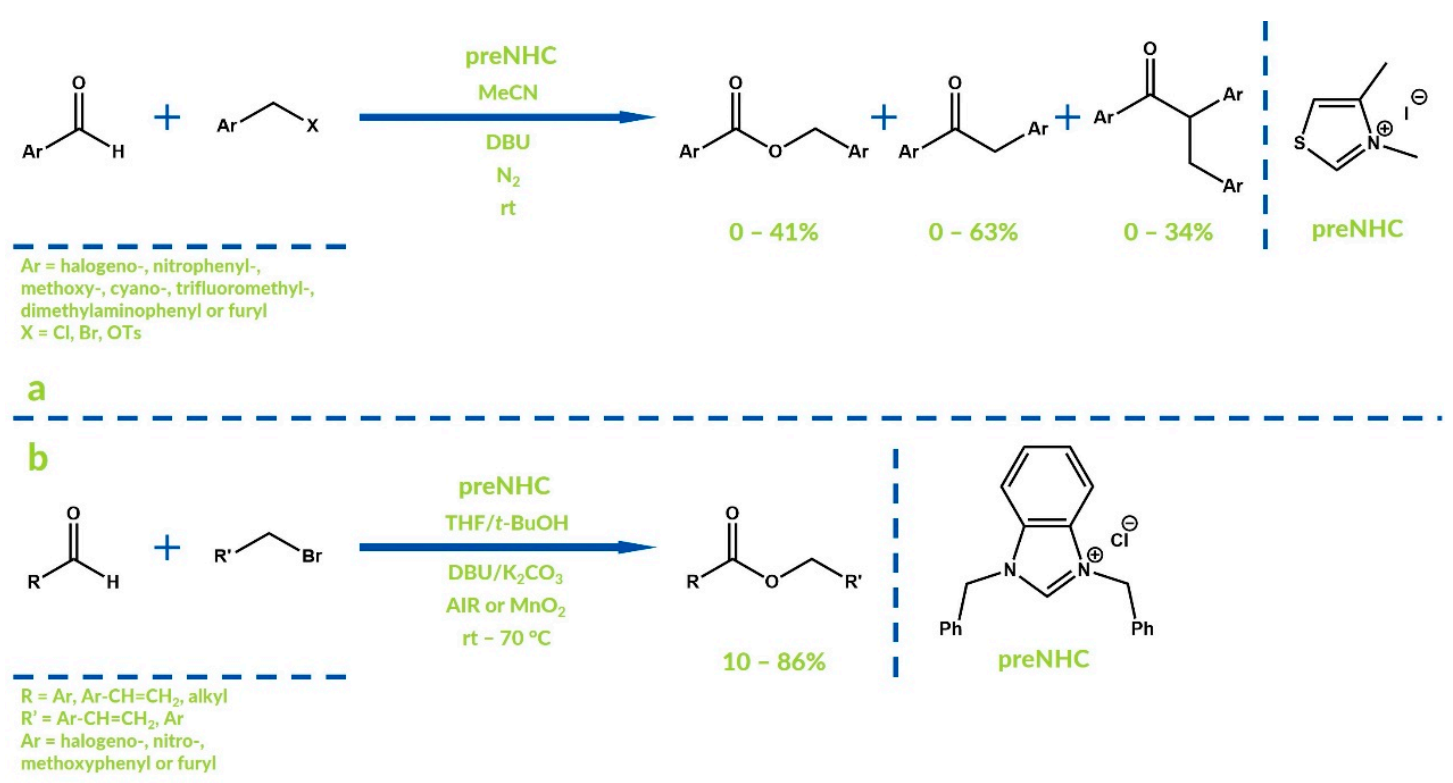

Figure 4. Synthesis reported by Deng et al. (a) and synthesis reported by Liu et al. (b).

Hui and co-workers developed a reaction of benzaldehyde with alkyl bromides and tosylates, with 1,3-dimesitylimidazolium chloride as a precatalyst, in which alkyl benzoates were obtained with relatively good yields [37]. In all the aforementioned procedures DBU (1,8-diazabicyclo[5.4.0]undec-7-ene) was used as a base. In turn, in 2011 Youn and co-workers reported the synthesis of phtalides and isocoumarins in oxygenative NHC-catalytic intramolecular reactions of $o$-alkynyl benzaldehydes [37]. It was the first example of an oxygenative NHC-catalyzed cyclization reaction. Regioselectivity of the examined process depends strongly on the $\mathrm{R}$ substituent nature and varies between <99:1 and 17:83 (Figure 5).

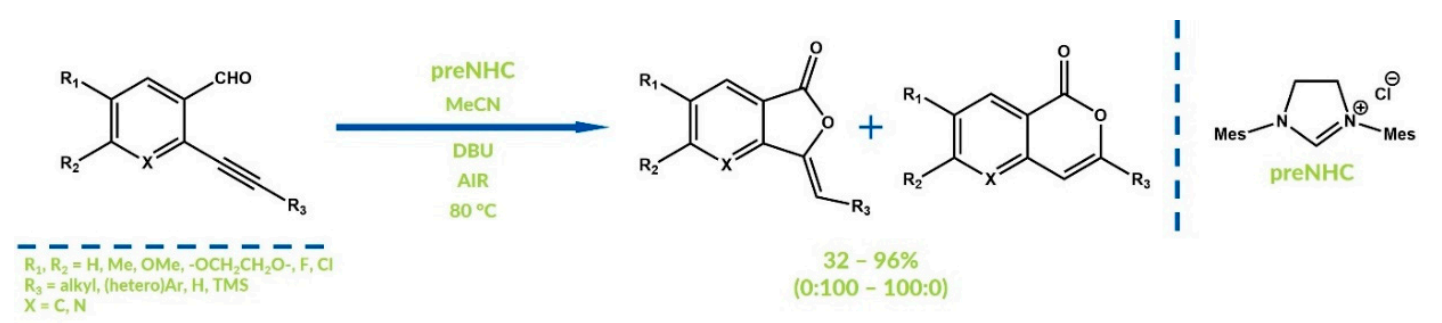

Figure 5. Synthesis reported by Youn and co-workers.

Aryl esters can be obtained also via the oxygenative NHC reaction of aldehydes with boronic acids. Anand et al. reported this aerobic approach to obtain aryl esters with moderate to excellent yields in 2012 (Figure 6) [38].

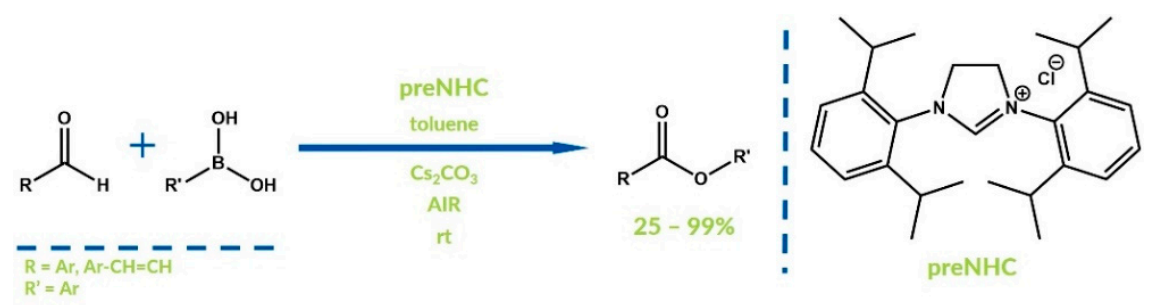

Figure 6. Synthesis reported by Anand and co-workers.

Synthesis of amides via NHC catalysis under aerobic conditions is also possible. Soeta, Ukaji et al. reported the synthesis of $N$-acylureas from ureas and $N, N^{\prime}$-disubstituted carbodiimides in 2013 [39]. 
Imidazolinium salt was used as a precatalyst and potassium carbonate as a base. The expected products were obtained with excellent yields of up to $93 \%$.

\section{Oxidative NHC Catalysis}

Synthesis of esters and carboxylic acids via oxidative NHC catalysis with the addition of alcohols or water, respectively, as nucleophiles is a well-developed reaction model. It is especially worth noting the research published by, among others, Struder, Zeitler or Scheidt [40-49]. Initially, the oxidative path was applied to the synthesis of benzoic acid esters derivatives. Connon et al. reported the synthesis of similar species in the reaction of benzaldehydes with primary and secondary alcohols in 2008 (Figure 7) [50]. In this case, azobenzene was used as an oxidizer and 3-benzylthiazolium bromide as a precatalyst.

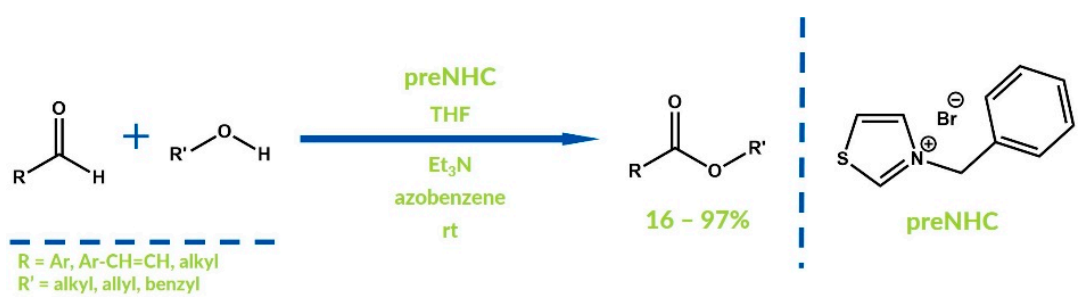

Figure 7. NHC-catalyzed ester oxidative synthesis by Connon et al.

Maki and Scheidt developed the oxidative reaction of aliphatic aldehydes with alcohols catalyzed by carbene liberated from 1,3-dimethylimidazolium iodide [41]. Manganese(IV) oxide was used as an external oxidizer, and the expected products were obtained with very high yields of up to $99 \%$.

It is also possible to design tandem oxidation reactions in which one step is the NHC-catalyzed oxidation process. Rose and Zeitler performed a domino protocol of the oxidation of 2-(hydroxyethoxy)benzyl alcohols to cyclic lactones in 2010 (Figure 8) [45]. In the first step, a benzyl hydroxyl group was oxidized to aldehyde by manganese(IV) oxide and, then, the intramolecular reaction of oxidative NHC-catalyzed esterification occurred. Azobenzene was used in this case as an equimolar oxidizer.

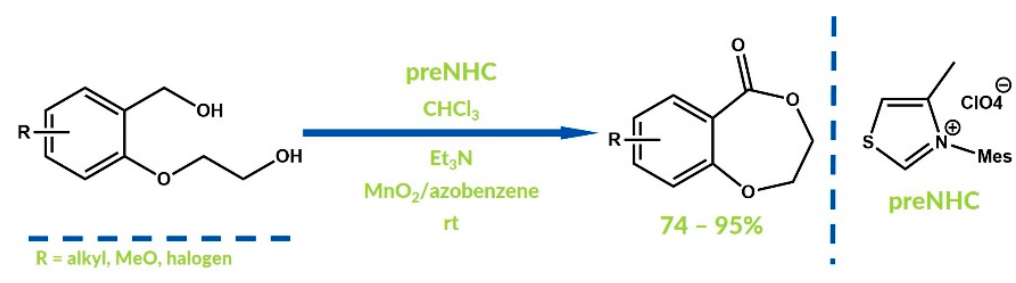

Figure 8. Domino oxidation by Rose and Zeitler.

Kang and Jang published a similar reaction of esterification of allyl alcohols resulting in allyl cinnamates formation in 2014 (Figure 9) [51]. In the first step, allyl alcohol is oxidized by TEMPO $((2,2,6,6$-Tetramethylpiperidin-1-yl)oxyl) to aldehyde, which reacts then with the carbene present in the reaction mixture. Oxidation of the Breslow intermediate is followed by TEMPO in two steps via SET, and results in a radical cation formation which is finally oxidized to an acylazolium. High yields of oxidative esterification are promoted by the addition of hexafluoroisopropyl alcohol (HFIP). Moreover, the oxidizer is recyclable because it undergoes oxidation by oxygen from air. 


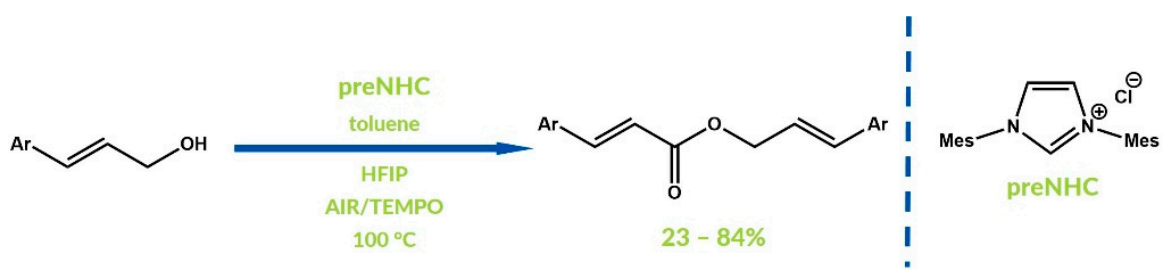

Figure 9. Synthesis reported by Kang and Jang.

As mentioned, the Kang and Jang method can be recognized as one of the first examples of the exceptional cooperative NHC-catalyzed oxidative reaction which occurs with the use of electron-transfer mediators (ETMs). Studer's group reported an aerobic NHC-catalyzed oxidation of aldehydes to esters in 2013 (Figure 10) [52]. Oxygen from air is not a direct oxidizer but oxidizes the ruthenium(I) complex generated via reduction of the ruthenium(II) complex added to the reaction mixture. The ruthenium(II) complex participates in Breslow intermediate oxidation to acylazolium. This approach, with the use of ruthenium complexes as ETMs, prevents aerobic oxidation of aldehydes to carboxylic acids and enables the expected products to be obtained with moderate to good yields. Moreover, during cooperative oxidative NHC catalysis, less than equimolar amounts of direct oxidizers are used.

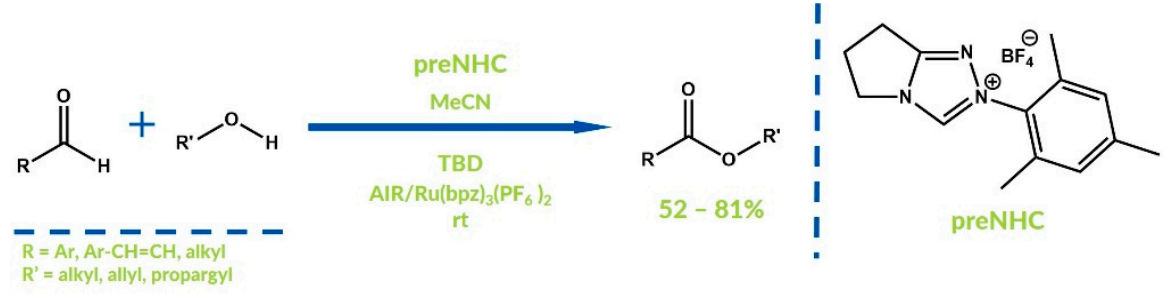

Figure 10. Struder's protocol with use of ruthenium compounds as ETM.

Sundén and co-workers reported the aerobic NHC-catalyzed synthesis of dihydropyranones via multistep electron transfer in 2016 (Figure 11) [53]. The assumption of this work is the oxidation of ETM first, by oxygen from air. The first ETM oxidizes, then the second ETM, which is the final oxidizer in the NHC-catalyzed reaction. The expected dihydropyranones were obtained with moderate to good yields and excellent enantiomeric excesses. In the same year, Sundén's group reported similar oxidative esterification of aldehydes [54]. Moreover, iron [48] and palladium [55] compounds were also recognized as ETMs in similar reactions.

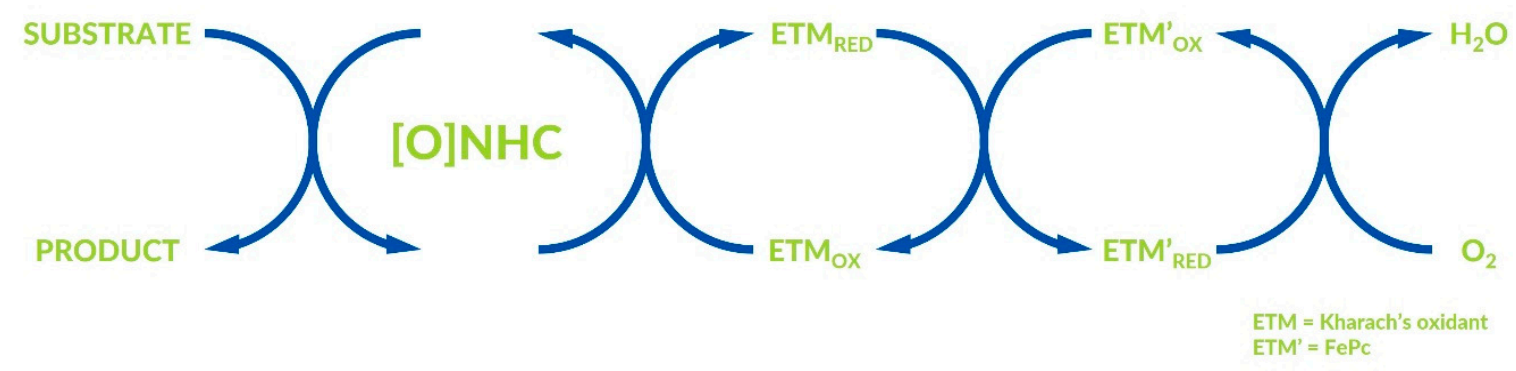

Figure 11. Multistep electron transfer by Sundén and co-workers.

Direct oxidation of the Breslow intermediate to acylazolium by oxygen from air is also possible. Blechert et al. reported the NHC-catalyzed oxidation of aldehydes to carboxylic acids with the addition of mesoporous graphitic carbon nitride $\left(\mathrm{mpg}-\mathrm{C}_{3} \mathrm{~N}_{4}\right)$ as a photocatalyst in 2013 (Figure 12) [56]. Various carboxylic acids were obtained with moderate to good yields. Furthermore, the authors considered that the possible oxygenative path of the investigated mechanism occurs in the minority of cases. 

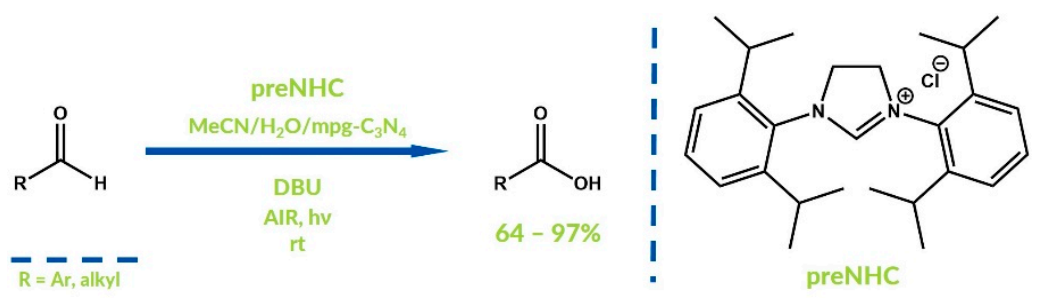

Figure 12. Protocol reported by Blechert et al.

Sudalai et al. reported the NHC-catalyzed esterification of aromatic aldehydes by alcohols under aerobic conditions in 2013 [57]. Various esters were obtained with moderate yields without the addition of ETMs or other catalysts. In this case, 1,3-dimesitylimidazolium chloride was used as a precatalyst and DBU as a base. The reaction was carried out in THF with the addition of methanol as a reagent. Shortly thereafter, Zeitler and Connon showed a similar aerobic oxidation of aromatic aldehydes, but in general with better yields [58]. In their procedure, triazolium salt was used as a precatalyst, DBU as a base, and THF as a solvent. Nonetheless, a considerable excess of methanol as a reactant was added to the reaction mixture.

In 2010, Nair and co-workers reported the NHC-catalyzed oxidation of benzaldehydes to benzoic acids using carbon dioxide as an oxidant [59]. According to the authors, the Breslow intermediate was oxidized by carbon dioxide with the liberation of carbon monoxide. The expected aromatic carboxylic acids were obtained with moderate to high yields. One year earlier, Gu and Zhang presented a catalyzed by NHC oxidation of aromatic aldehydes (including cinnamaldehydes) to carboxylic acids [60]. As an oxidant, carbon dioxide was also used, but the authors provided the mechanism with the NHC-catalyzed step of $\mathrm{CO}_{2}$ reduction. $\mathrm{Gu}$ and Zhang assumed that aldehyde molecules were directly oxidized by oxygen from the carbon dioxide-NHC complex. In this case, products were obtained with differentiated yields. Bode and co-workers published an article developing earlier research into the oxidizing properties of carbon dioxide in NHC catalysis in 2011 [61]. Their experiments proved that molecular oxygen, instead of $\mathrm{CO}_{2}$, plays the role of the oxidizing agent in the mentioned reactions (Figure 13). Nonetheless, carbon dioxide prevents formation of side products via aldehyde dimerization or oligomerization.

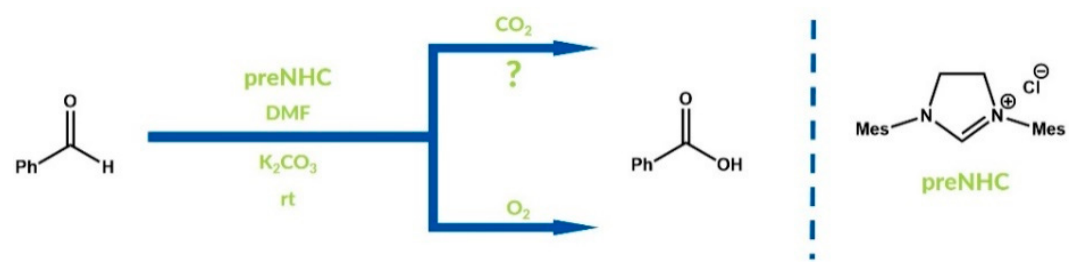

Figure 13. Difference between Zhang's and Bode's conclusions.

As is well known, reactions promoted by chiral NHC-catalysts enable the synthesis of enantiomerically enriched products. Scheidt's group reported the dessymetrization of cis-1,2-cyclohexanediol by cinnamic aldehyde oxidative esterification in 2007 [62]. They obtained a monocinnamate ester with $80 \%$ ee and $58 \%$ yield (Figure 14 ).

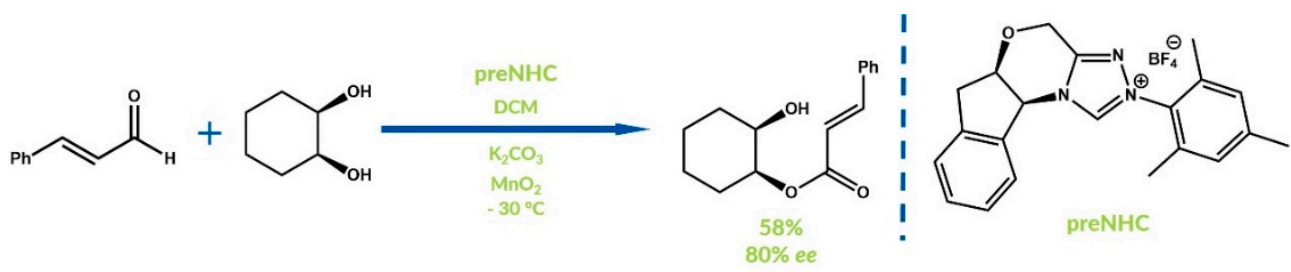

Figure 14. Synthesis reported by Scheidt and co-workers. 
In 2011, Iida and Yashima reported an analogous reaction of the dessymetrization of cis-1,2-cyclohexanediol via oxidative catalytic benzoylation using triazolium salt as the NHC precursor and riboflavin as the co-catalyst [49]. Yields and enantiomeric excesses were lower than results showed in Scheidt's work. Notwithstanding, the developed procedure was an aerobic oxidation, which is a considerable advantage.

You and co-workers developed the oxidative NHC-catalyzed Claisen rearrangement in 2015 [63]. Bicyclic dihydropyranone-fused naphtols were obtained with generally high yields and moderate to good enantiomeric excesses. As an oxidant, the sterically hindered quinone reported in 1957 by Kharasch was used (Figure 15) [64]. More importantly, in this reaction, not only carbon-heteroatom bonds were generated but also a novel carbon-carbon bond was formed (Figure 16).

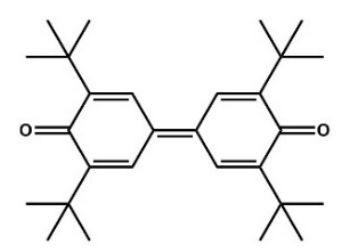

Figure 15. Kharasch's oxidant.

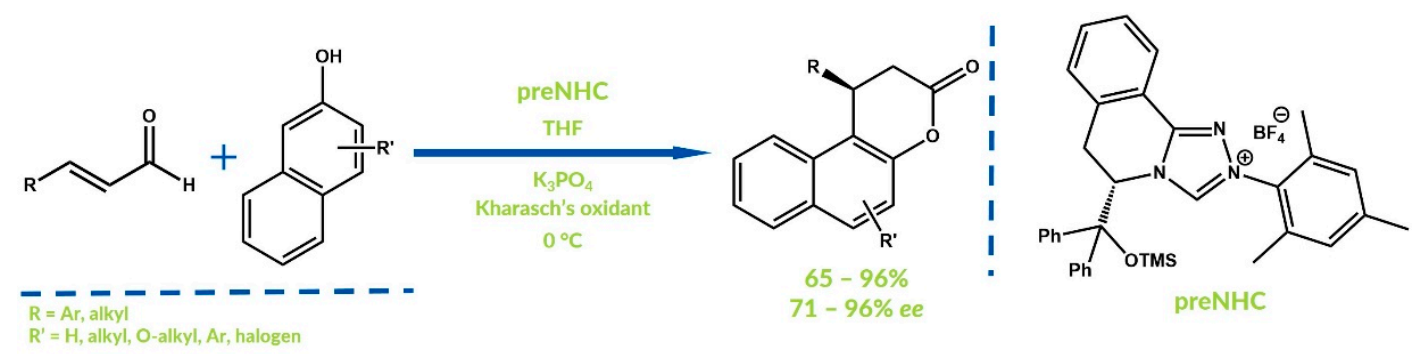

Figure 16. Claisen rearrangement by You and co-workers.

In 2018, Chi et al. reported the enantioselective NHC-catalyzed oxidative coupling of enals and di(hetero)arylmethanes (Figure 17) [65]. In one of the proposed mechanisms, there occurs a Claisen rearrangement or 1,4-addition, between the generated acylazolium and di(hetero)arylmethane derivative. Another mechanism assumes oxidation via SET. The authors obtained the expected products with high yields and excellent enantioselectivities.

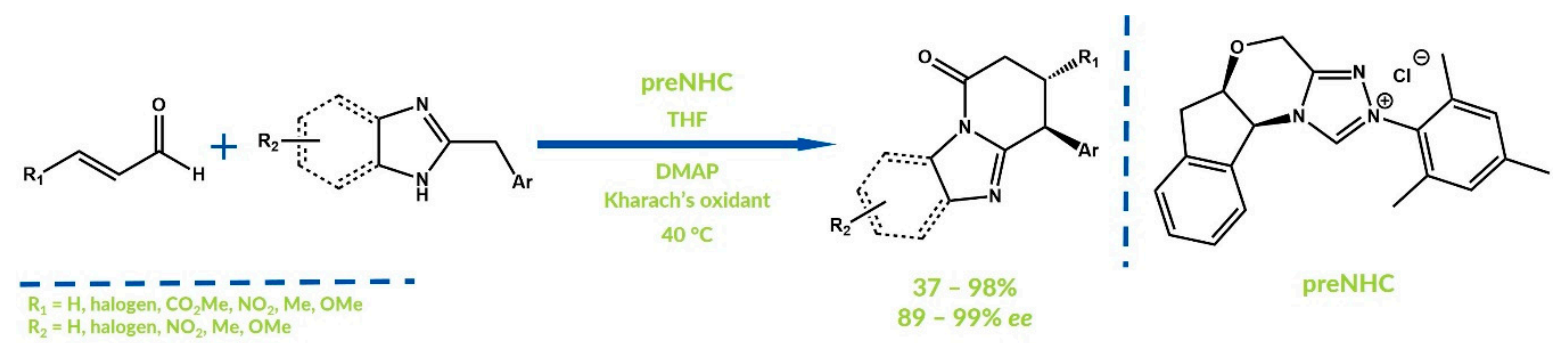

Figure 17. Synthesis reported by Chi and co-workers.

In 2018, Yang, Chi and co-workers reported the NHC-catalyzed oxidative acylation of 1,2-diols by aldehydes with high site-selectivities (Figure 18) [66]. The authors obtained various hydroxyesters acylated at primary hydroxyl groups with moderate yields and enantiomeric excesses. 


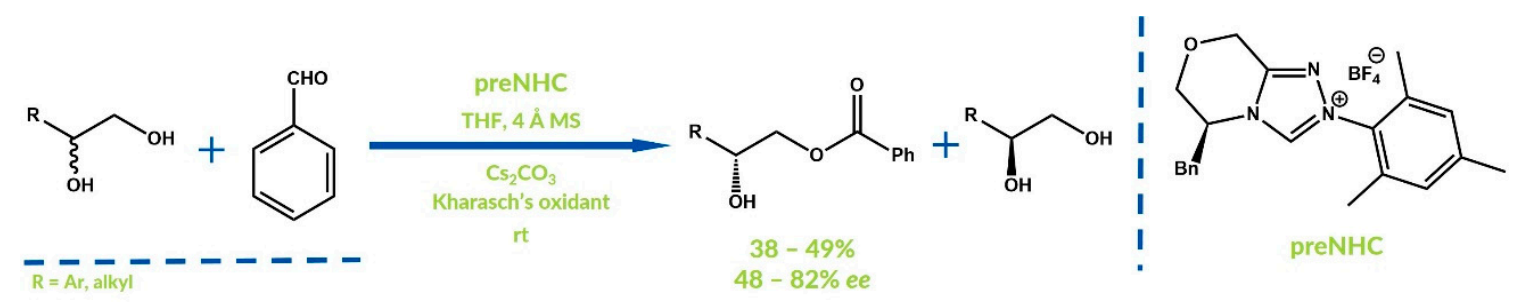

Figure 18. Synthesis reported by Yang, Chi et al.

Synthesis of amides and thioesters via oxidative NHC-catalyzed reactions is also possible. In 2011, some examples of enantiomerically enriched benzoic acid amides and thioesters were synthesized from benzaldehydes and racemic amines and thiols by lida and Yashima, with moderate yields and very low enantiomeric excesses below 9\% [49].

In 2017, Ma et al. showed that direct $N$-acylation of amides by aldehydes in oxidative NHC-catalyzed reaction is also possible [67]. Various carboxylic or sulfonic acids amides were acylated by diverse aldehydes with good yields. Bode et al. reported an enentioselective oxidative approach for the synthesis of dihydropyridinones via an NHC-catalyzed aza-Claisen rearrangement in 2011 (Figure 19) [68]. Kharasch's oxidizer was also used as an external oxidant. Various examples of unprotected dihydropyridinones were obtained with high yields and good enantioselectivities.

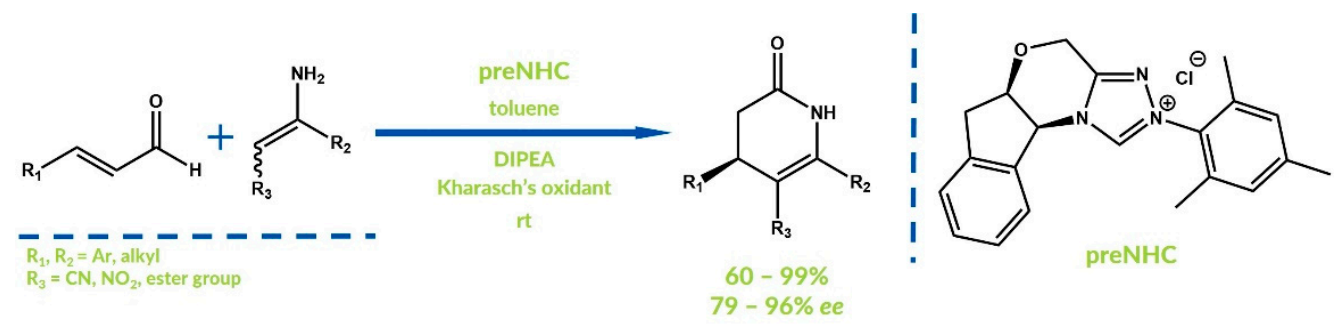

Figure 19. Aza-Claisen rearrangement by Bode et al.

Less popular than the two-electron oxidation of the Breslow intermediate is oxidation via the SET process, in which instead of an acylazolium ion, a very reactive radical cation species is generated. These intermediates can undergo reactions with other radicals present in the reaction mixture. $\mathrm{Li}$, Webster and Chi reported the $\beta, \beta$-coupling of $\alpha, \beta$-unsaturated nitroalkanes in the presence of aldehyde, methanol and an NHC catalyst in 2014 (Figure 20) [69]. SET oxidation was guaranteed by pyruvate ferredoxin oxidoreductase (PFOR). Structurally complex products were obtained with high yields and moderate diastereomeric excesses.

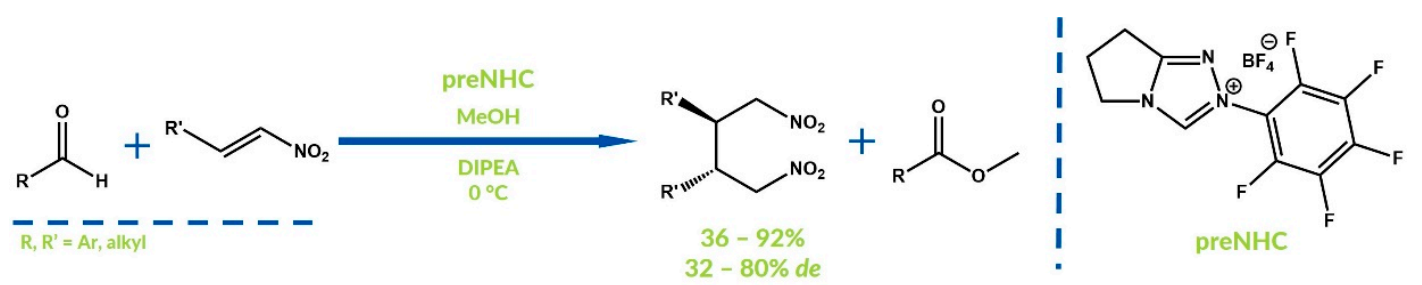

Figure 20. Synthesis reported by Li, Webster, and Chi.

Sun and Ye developed the oxidative [3 + 2] annulation of dioxindoles and enals in 2017 [70]. The expected products were obtained in the efficient radical cross-coupling of homoenolate or enolate. Nitrobenzene was used as an oxidizing agent and triazolium salts as precatalysts (Figure 21). The developed approach was distinguished as a highly diastereoselective and enantioselctive method. One year later, Ye et al. reported a similar synthesis using $\beta, \beta$-disubstituted enals [71]. 


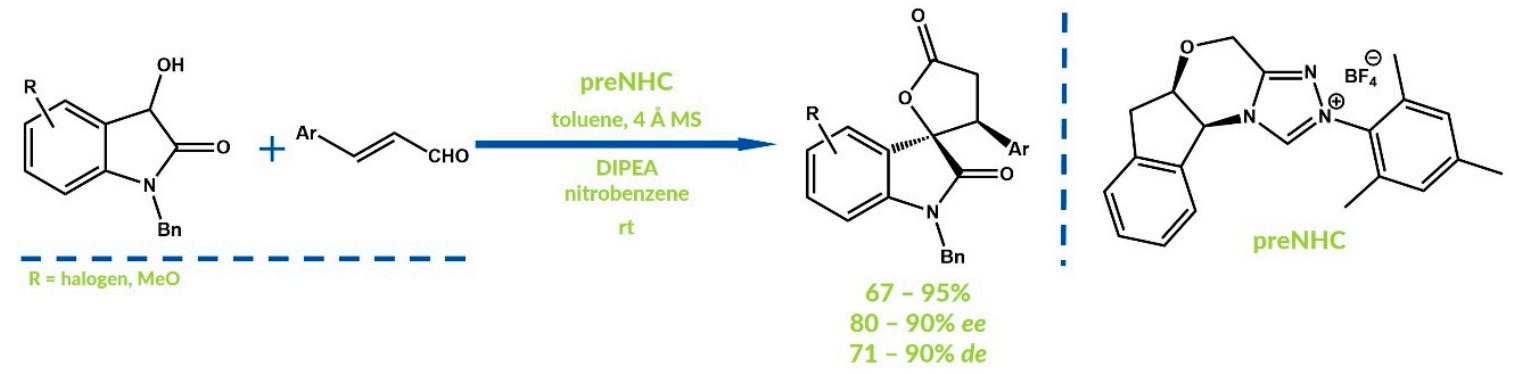

Figure 21. Synthesis reported by Sun and Ye.

SET oxidations of the Breslow intermediate are convenient enantioselective syntheses of 2-hydroxyketones via $\beta$-hydroxylation of enals [72,73]. Moreover, homo- and cross-coupling of enals, resulting in 3,4-diarylcyclopentanones, is also possible with moderate to good ee values [74]. Applications of radical species generated in SET oxidation of the Breslow intermediate are very promising with this continuously developing synthetic approach [75].

NHC catalysis under oxidizing conditions does not only occur via oxidation of the Breslow intermediate. Several examples of the oxidizing of other species during the NHC-catalyzed reaction have been reported. In 2006, Ding's group developed an $N$-tosylaziridines ring opening using aldehydes under aerobic conditions (Figure 22) [76]. The resulting esters of 2-aminoalcohols arose via oxidation of the intermediate which was generated after the aziridine ring opening with the Breslow intermediate. The final products were obtained with moderate to high yields and, in several cases, very good regioselectivities.

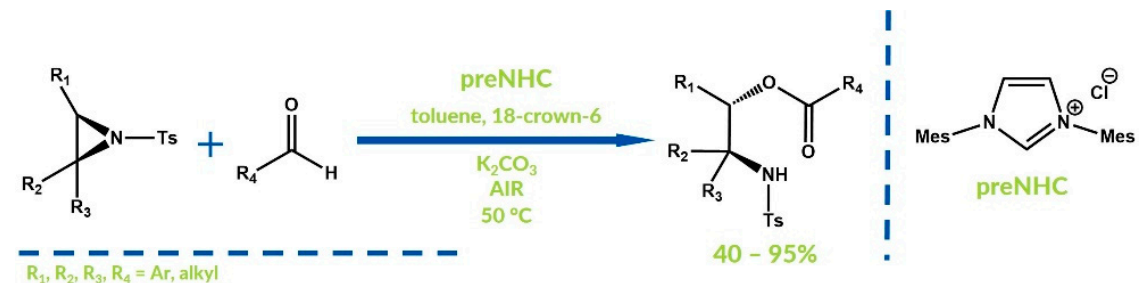

Figure 22. $\mathrm{N}$-tosylaziridines ring opening by Ding and co-workers.

Recently Zeitler and Connon have reported oxidative esterification of aldehydes occurring via oxidation of benzoin, generated by the condensation of two molecules of benzaldehydes [77]. Furthermore, the obtained benzidin reacts with carbene to give the Breslow intermediate, which subsequently reacts with the corresponding alcohol. After elimination, esters of benzoic acids are obtained with good yields (Figure 23).

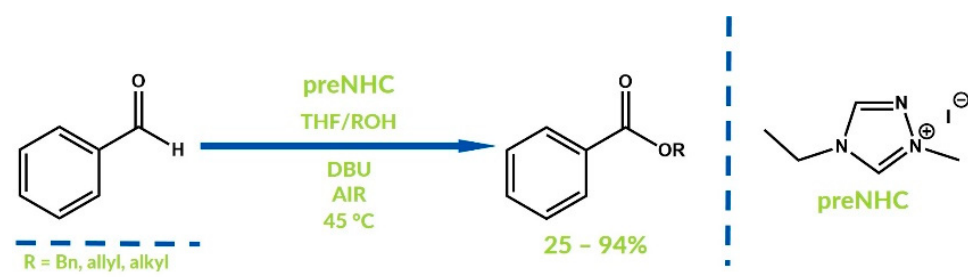

Figure 23. Synthesis of benzoic acid esters by Zeitler and Connon.

In 2015 Sudalai et al. reported the synthesis of $\alpha, \beta$-epoxyketones via the oxidative NHC-catalyzed coupling of alkenes with aldehydes [78]. Styrene derivative was firstly oxidized by NBS (N-bromosuccinimide) and DMSO to phenacyl bromide. The resulting acylazolium reacted then with a second molecule of aldehyde and, after elimination, $\alpha, \beta$-epoxyketones were obtained with moderate to good yields (Figure 24). 


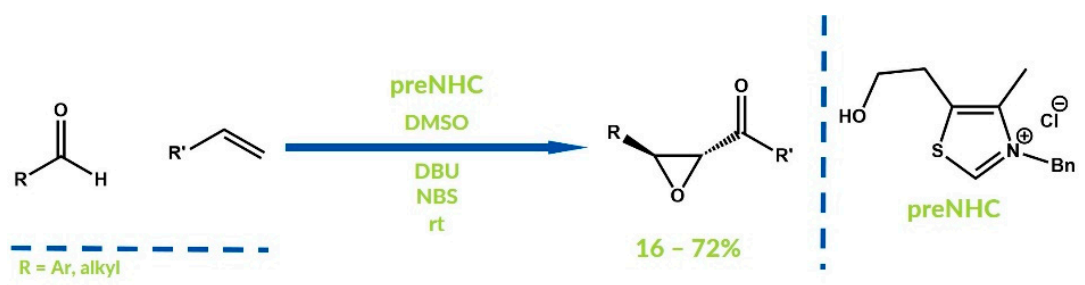

Figure 24. Synthesis reported by Sudalai et al.

\section{Oxidative NHC Catalysis via Electrolysis}

The Breslow intermediate can also be oxidized to an acylazolium ion by anodic electrochemical oxidation. Cyclic voltammograms of Breslow intermediates lead to low oxidation potentials-approximately $0.5 \mathrm{~V}$ for first and $0.9 \mathrm{~V}$ for second step of the oxidation [79]. In 2012, Boydstone and co-workers reported the synthesis of esters in an NHC-catalyzed reaction of aldehydes and alcohols in an undivided electrochemical cell (Figure 25) [80]. Essentially, the reaction procedure with oxidation of the Breslow intermediate via electrolysis does not differ from an approach with an external oxidizer. The fundamental difference is the necessity of an electrolyte addition. In Boystone's work, tetrabutylammonium bromide (TBAB) was added as an electrolyte. The expected esters were obtained with excellent yields.
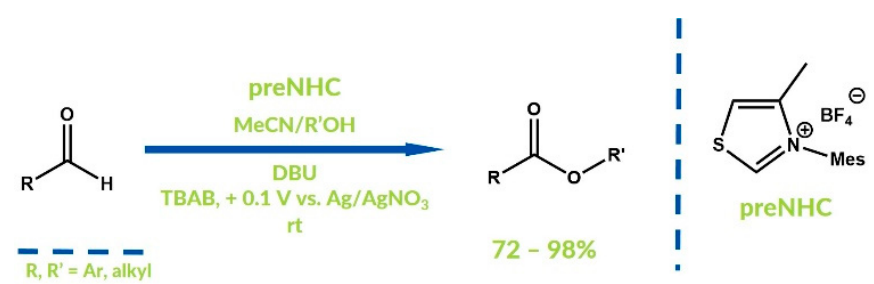

Figure 25. Electrochemical NHC esterification reported by Boydstone et al.

Brown et al. reported the analogous synthesis of esters [81] and amides [82] using a microflow electrochemical cell (Figure 26). Although good product yields were achieved, Brown's procedure has an enormous disadvantage- $\mathrm{NHC}$ salt must be added as an equimolar reagent. Boydstone's group showed a similar procedure of thioesters synthesis in an undivided cell in 2014 [83]. The reported approach enables product synthesis with good-to-excellent yields, but disulfide byproducts were observed in some cases.

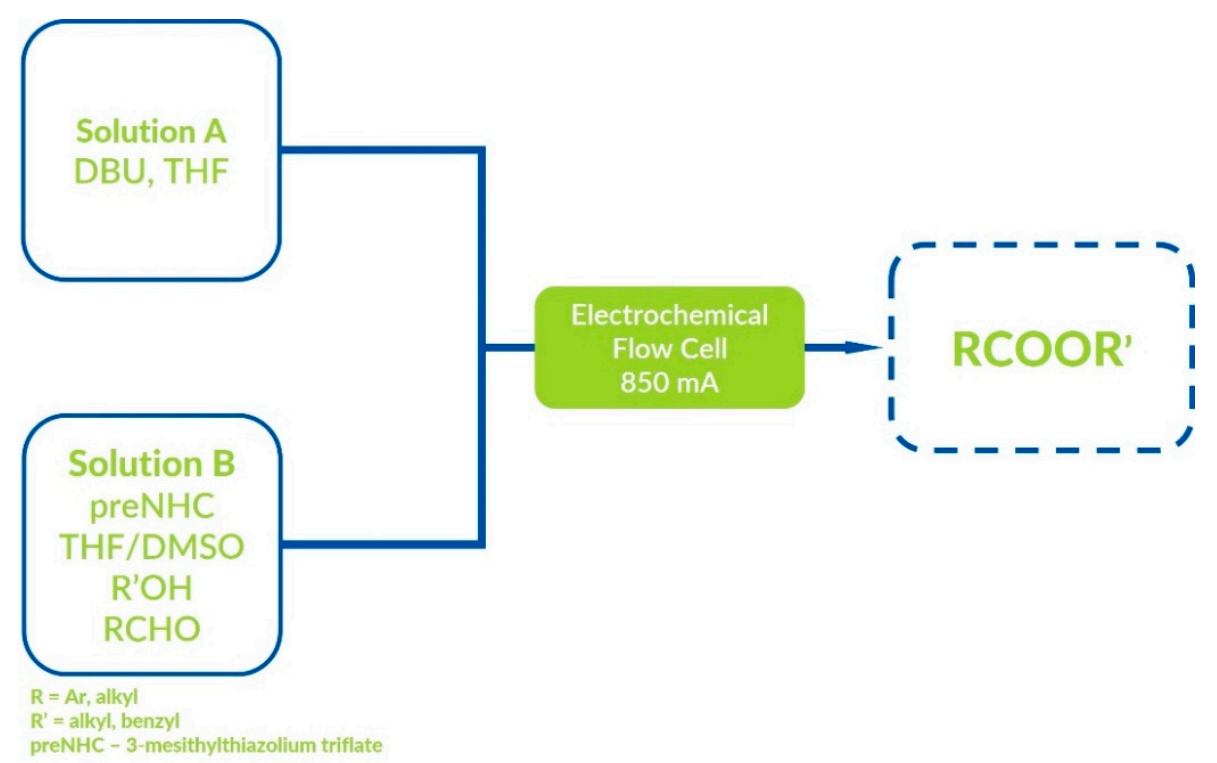

Figure 26. Microflow electrochemical cell used by Brown and co-workers. 


\section{Conclusions}

$\mathrm{N}$-Heterocyclic carbene catalysis under oxidizing conditions enables several diverse synthetic approaches. Various oxidizing mechanisms, oxidizers, and exploitation of domino reactions or cooperative catalysis extends the capabilities and applications of NHC catalysis under oxidizing conditions in organic synthesis. This branch of organocatalysis has been extensively developed in recent years, giving hope for the future discovery of novel elegant synthetic procedures. Significantly large amounts of complex organic molecules and important substrates in the total synthesis of natural products and pharmaceuticals can be obtained via procedures implementing oxidative and oxygenative NHC catalysis. Many esters, amides, thioesters, lactones, and lactames-frequently enantioenriched-synthesized by organocatalytic approaches can be very appropriable reactants in sophisticated syntheses. The future development of NHC catalysis under oxidizing conditions probably will be premised on electroorganic chemistry and photochemistry. Increasingly ideal equipment for electrosynthesis and common applications of photoinduced reactions in organocatalysis are leading to progress in this branch of organic chemistry.

Author Contributions: K.D. and Z.R. wrote the paper.

Funding: The project is co-financed by the National Science Center as part of the SONATA BIS program. (UMO-2016/22/E/ST5/00469).

Conflicts of Interest: The authors declare no conflict of interest.

\section{References}

1. Flanigan, D.M.; Romanov-Michailidis, F.; White, N.A.; Rovis, T. Organocatalytic Reactions Enabled by N-Heterocyclic Carbenes. Chem. Rev. 2015, 115, 9307-9387. [CrossRef] [PubMed]

2. Bugaut, X.; Glorius, F. Organocatalytic umpolung: N-heterocyclic carbenes and beyond. Chem. Soc. Rev. 2012, 41, 3511-3522. [CrossRef] [PubMed]

3. Douglas, J.; Churchill, G.; Smith, A.D. NHCs in asymmetric organocatalysis: Recent advances in azolium enolate generation and reactivity. Synthesis 2012, 44, 2295-2309. [CrossRef]

4. Izquierdo, J.; Hutson, G.E.; Cohen, D.T.; Scheidt, K.A. A continuum of progress: Applications of N-hetereocyclic carbene catalysis in total synthesis. Angew. Chem. Int. Ed. 2012, 51, 11686-11698. [CrossRef] [PubMed]

5. Nair, V.; Menon, R.S.; Biju, A.T.; Sinu, C.R.; Paul, R.R.; Jose, A.; Sreekumar, V. Employing homoenolates generated by NHC catalysis in carbon-carbon bond-forming reactions: State of the art. Chem. Soc. Rev. 2011, 40, 5336-5346. [CrossRef] [PubMed]

6. Rafiński, Z.; Kozakiewicz, A. Enantioselective Synthesis of Chromanones Bearing Quaternary Substituted Stereocenters Catalyzed by (1R)-Camphor-Derived N-Heterocyclic Carbenes. J. Org. Chem. 2015, 80, 7468-7476. [CrossRef] [PubMed]

7. Rafiński, Z. Enantioselective benzoin condensation catalyzed by spirocyclic terpene-based $N$-heterocyclic carbenes. Tetrahedron 2016, 72, 1860-1867. [CrossRef]

8. Rafiński, Z. Novel (-)- $\beta$-Pinene-Derived Triazolium Salts: Synthesis and Application in the Asymmetric Stetter Reaction. Chem CatChem 2016, 8, 2599-2603. [CrossRef]

9. Breslow, R. On the Mechanism of Thiamine Action. IV. Evidence from Studies on Model Systems. J. Am. Chem. Soc. 1958, 80, 3719-3726. [CrossRef]

10. Menon, R.S.; Biju, A.T.; Nair, V. Recent advances in N-heterocyclic carbene (NHC)-catalysed benzoin reactions. Beilstein J. Org. Chem. 2016, 12, 444-461. [CrossRef] [PubMed]

11. Rehbein, J.; Ruser, S.M.; Phan, J. NHC-catalysed benzoin condensation-is it all down to the Breslow intermediate? Chem. Sci. 2015, 6, 6013-6018. [CrossRef] [PubMed]

12. Ryan, S.J.; Candish, L.; Lupton, D.W. $N$-heterocyclic carbene-catalyzed generation of $\alpha, \beta$-unsaturated acyl imidazoliums: Synthesis of dihydropyranones by their reaction with enolates. J. Am. Chem. Soc. 2009, 131, 14176-14177. [CrossRef] [PubMed]

13. Candish, L.; Lupton, D.W. The Total Synthesis of Carbene Catalyzed Rearrangement of $\alpha, \beta$-Unsaturated Enol Esters. Org. Lett. 2010, 12, 4836-4839. [CrossRef] [PubMed] 
14. Ryan, S.J.; Stasch, A.; Paddon-Row, M.N.; Lupton, D.W. Synthetic and Quantum Mechanical Studies into the N-Heterocyclic Carbene Catalyzed (4+2) Cycloaddition. J. Org. Chem. 2012, 77, 1113-1124. [CrossRef] [PubMed]

15. Ryan, S.J.; Schimler, S.D.; Bland, D.C.; Sanford, M.S. Acyl azolium fluorides for room temperature nucleophilic aromatic fluorination of chloro- and nitroarenes. Org. Lett. 2015, 17, 1866-1869. [CrossRef] [PubMed]

16. Gillard, R.M.; Fernando, J.E.M.; Lupton, D.W. Enantioselective N-Heterocyclic Carbene Catalysis via the Dienyl Acyl Azolium. Angew. Chem. Int. Ed. 2018, 57, 4712-4716. [CrossRef] [PubMed]

17. Zeitler, K. Stereoselective synthesis of $(E)-\alpha, \beta$-unsaturated esters via carbene-catalyzed redox esterification. Org. Lett. 2006, 8, 637-640. [CrossRef] [PubMed]

18. Zhu, Z.Q.; Xiao, J.C. N-heterocyclic carbene-catalyzed reaction of alkynyl aldehydes with 1,3-keto esters or 1,3-diketones. Adv. Synth. Catal. 2010, 352, 2455-2458. [CrossRef]

19. Kaeobamrung, J.; Mahatthananchai, J.; Zheng, P.; Bode, J.W. An enantioselective claisen rearrangement catalyzed by N-heterocyclic carbenes. J. Am. Chem. Soc. 2010, 132, 8810-8812. [CrossRef] [PubMed]

20. Zhao, C.; Guo, D.; Munkerup, K.; Huang, K.W.; Li, F.; Wang, J. Enantioselective [3 + 3] atroposelective annulation catalyzed by N-heterocyclic carbenes. Nat. Commun. 2018, 9, 611. [CrossRef] [PubMed]

21. Yao, C.; Wang, D.; Lu, J.; Li, T.; Jiao, W.; Yu, C. N-Heterocyclic Carbene Catalyzed Reactions of $\alpha$-Bromo- $\alpha, \beta$-unsaturated Aldehydes $/ \alpha, \beta$-Dibromoaldehydes with 1,3-Dinucleophilic Reagents. Chem. A Eur. J. 2012, 18, 1914-1917. [CrossRef] [PubMed]

22. Zhang, B.; Feng, P.; Cui, Y.; Jiao, N. NHC-catalyzed C-O or C-N bond formation: Efficient approaches to $\alpha, \beta$-unsaturated esters and amides. Chem. Commun. 2012, 48, 7280-7282. [CrossRef] [PubMed]

23. Wang, X.B.; Zou, X.L.; Du, G.F.; Liu, Z.Y.; Dai, B. Nucleophilic carbene-catalyzed redox-esterification reaction of $\alpha$-halo- $\alpha, \beta$-unsaturated aldehyde. Tetrahedron 2012, 68, 6498-6503. [CrossRef]

24. Lang, M.; Wang, J. N-Heterocyclic Carbene-Catalyzed Enantioselective $\beta$-Amination of $\alpha$-Bromoenals Enabled by a Proton-Shuttling Strategy. Eur. J. Org. Chem. 2018, 2018, 2958-2962. [CrossRef]

25. Mahatthananchai, J.; Zheng, P.; Bode, J.W. $\alpha, \beta$-Unsaturated acyl azoliums from $N$-heterocyclic carbene catalyzed reactions: Observation and mechanistic investigation. Angew. Chem. Int. Ed. 2011, 50, 1673-1677. [CrossRef] [PubMed]

26. Samanta, R.C.; Maji, B.; De Sarkar, S.; Bergander, K.; Fröhlich, R.; Mück-Lichtenfeld, C.; Mayr, H.; Studer, A. Nukleophile Addition von Enolen und Enaminen an $\alpha, \beta$-ungesättigte Acylazoliumionen: Mechanistische Studien. Angew. Chem. 2012, 124, 5325-5329. [CrossRef]

27. Alanthadka, A.; Maheswari, C.U. N-heterocyclic carbene-catalyzed oxidative amidation of aldehydes with amines. Adv. Synth. Catal. 2015, 357, 1199-1203. [CrossRef]

28. Vellalath, S.; Romo, D. Asymmetric Organocatalysis: The Emerging Utility of $\alpha, \beta$-Unsaturated Acylammonium Salts. Angew. Chem. Int. Ed. 2016, 55, 13934-13943. [CrossRef] [PubMed]

29. Zhang, C.; Hooper, J.F.; Lupton, D.W. N-Heterocyclic Carbene Catalysis via the $\alpha, \beta$-Unsaturated Acyl Azolium. ACS Catal. 2017, 7, 2583-2596. [CrossRef]

30. Wang, M.H.; Scheidt, K.A. Cooperative Catalysis and Activation with N-Heterocyclic Carbenes. Angew. Chem. Int. Ed. 2016, 55, 14912-14922. [CrossRef] [PubMed]

31. Knappke, C.E.I.; Imami, A.; JacobivonWangelin, A. Oxidative N-Heterocyclic Carbene Catalysis. Chem CatChem 2012, 4, 937-941. [CrossRef]

32. De Sarkar, S.; Biswas, A.; Samanta, R.C.; Studer, A. Catalysis with N-heterocyclic carbenes under oxidative conditions. Chem. A Eur. J. 2013, 19, 4664-4678. [CrossRef] [PubMed]

33. Bortolini, O.; Chiappe, C.; Fogagnolo, M.; Massi, A.; Pomelli, C.S. Formation, Oxidation, and Fate of the Breslow Intermediate in the $\mathrm{N}$-Heterocyclic Carbene-Catalyzed Aerobic Oxidation of Aldehydes. J. Org. Chem. 2017, 82, 302-312. [CrossRef] [PubMed]

34. Bhunia, A.; Thorat, S.; Gonnade, R.G.; Biju, A.T. Reaction of $N$-heterocyclic carbenes with chalcones leading to the synthesis of deoxy-Breslow intermediates in their oxidized form. Chem. Commun. 2015, 51, 13690-13693. [CrossRef] [PubMed]

35. Lin, L.; Li, Y.; Du, W.; Deng, W.P. The NHCs-mediated cross-coupling of aromatic aldehydes with benzyl halides: Synthesis of $\alpha$-aryl ketones. Tetrahedron Lett. 2010, 51, 3571-3574. [CrossRef]

36. Maji, B.; Vedachalan, S.; Ge, X.; Cai, S.; Liu, X.W. N-heterocyclic carbene-mediated oxidative esterification of aldehydes: Ester formation and mechanistic studies. J. Org. Chem. 2011, 76, 3016-3023. [CrossRef] [PubMed] 
37. Park, J.H.; Bhilare, S.V.; Youn, S.W. NHC-catalyzed oxidative cyclization reactions of 2-alkynylbenzaldehydes under aerobic conditions: Synthesis of O-Heterocycles. Org. Lett. 2011, 13, 2228-2231. [CrossRef] [PubMed]

38. Arde, P.; Ramanjaneyulu, B.T.; Reddy, V.; Saxena, A.; Anand, R.V. N-Heterocyclic carbene catalysed aerobic oxidation of aromatic aldehydes to aryl esters using boronic acids. Org. Biomol. Chem. 2012, 10, 848-851. [CrossRef] [PubMed]

39. Soeta, T.; Tabatake, Y.; Fujinami, S.; Ukaji, Y. N-heterocyclic carbene catalyzed oxidative coupling of aldehydes with carbodiimides under aerobic conditions: Efficient synthesis of $\mathrm{N}$-acylureas. Org. Lett. 2013, 15, 2088-2091. [CrossRef] [PubMed]

40. Guin, J.; De Sarkar, S.; Grimme, S.; Studer, A. Biomimetic carbene-catalyzed oxidations of aldehydes using TEMPO. Angew. Chem. Int. Ed. 2008, 47, 8727-8730. [CrossRef] [PubMed]

41. Maki, B.E.; Scheldt, K.A. N-heterocyclic carbene-catalyzed oxidation of unactivated aldehydes to esters. Org. Lett. 2008, 10, 4331-4334. [CrossRef] [PubMed]

42. Yoshida, M.; Katagiri, Y.; Zhu, W.B.; Shishido, K. Oxidative carboxylation of arylaldehydes with water by a Sulfoxylalkyl-substituted N-heterocyclic carbene catalyst. Org. Biomol. Chem. 2009, 7, 4062-4066. [CrossRef] [PubMed]

43. Maki, B.E.; Chan, A.; Phillips, E.M.; Scheidt, K.A. N-Heterocyclic carbene-catalyzed oxidations. Tetrahedron 2009, 65, 3102-3109. [CrossRef] [PubMed]

44. Goswami, S.; Hazra, A. One-step Direct Conversion of Heterocyclic Aldehydes to Esters. Chem. Lett. 2009, 38, 484-485. [CrossRef]

45. Rose, C.A.; Zeitler, K. Efficient catalytic, oxidative lactonization for the synthesis of benzodioxepinones using thiazolium-derived carbene catalysts. Org. Lett. 2010, 12, 4552-4555. [CrossRef] [PubMed]

46. De Sarkar, S.; Grimme, S.; Studer, A. NHC catalyzed oxidations of aldehydes to esters: Chemoselective acylation of alcohols in presence of amines. J. Am. Chem. Soc. 2010, 132, 1190-1191. [CrossRef] [PubMed]

47. Desarkar, S.; Biswas, A.; Song, C.H.; Studer, A. Kinetic resolution of secondary alcohols by NHC-catalyzed oxidative esterification. Synthesis 2011, 1974-1983. [CrossRef]

48. Reddy, R.S.; Rosa, J.N.; Veiros, L.F.; Caddick, S.; Gois, P.M.P. NHC/Iron cooperative catalysis: Aerobic oxidative esterification of aldehydes with phenols. Org. Biomol. Chem. 2011, 9, 3126-3129. [CrossRef] [PubMed]

49. Iwahana, S.; Iida, H.; Yashima, E. Oxidative esterification, thioesterification, and amidation of aldehydes by a two-component organocatalyst system using a chiral $N$-heterocyclic carbene and redox-active riboflavin. Chem. A Eur. J. 2011, 17, 8009-8013. [CrossRef] [PubMed]

50. Noonan, C.; Baragwanath, L.; Connon, S.J. Nucleophilic carbene-catalysed oxidative esterification reactions. Tetrahedron Lett. 2008, 49, 4003-4006. [CrossRef]

51. Kang, Y.W.; Jang, H.Y. NHC-catalyzed one-pot oxidation and oxidative esterification of allylic alcohols using TEMPO: The effect of alcohol additives. RSC Adv. 2014, 4, 44486-44490. [CrossRef]

52. Zhao, J.; Mück-Lichtenfeld, C.; Studer, A. Cooperative N-Heterocyclic Carbene (NHC) and Ruthenium Redox Catalysis: Oxidative Esterification of Aldehydes with Air as the Terminal Oxidant. Adv. Synth. Catal. 2013, 355, 1098-1106. [CrossRef]

53. Axelsson, A.; Hammarvid, E.; Ta, L.; Sundén, H. Asymmetric aerobic oxidative NHC-catalysed synthesis of dihydropyranones utilising a system of electron transfer mediators. Chem. Commun. 2016, 52, 11571-11574. [CrossRef] [PubMed]

54. Ta, L.; Axelsson, A.; Sundén, H. Attractive aerobic access to the $\alpha, \beta$-unsaturated acyl azolium intermediate: Oxidative NHC catalysis via multistep electron transfer. Green Chem. 2016, 18, 686-690. [CrossRef]

55. Zhang, M.; Zhang, S.; Zhang, G.; Chen, F.; Cheng, J. Palladium/NHC-catalyzed oxidative esterification of aldehydes with phenols. Tetrahedron Lett. 2011, 52, 2480-2483. [CrossRef]

56. Möhlmann, L.; Ludwig, S.; Blechert, S. NHC-catalysed highly selective aerobic oxidation of nonactivated aldehydes. Beilstein J. Org. Chem. 2013, 9, 602-607. [CrossRef] [PubMed]

57. Kiran, I.N.C.; Lalwani, K.; Sudalai, A. N-Heterocyclic carbene catalyzed esterification of aromatic aldehydes with alcohols under aerobic conditions. RSC Adv. 2013, 3, 1695-1698. [CrossRef]

58. Delany, E.G.; Fagan, C.L.; Gundala, S.; Mari, A.; Broja, T.; Zeitler, K.; Connon, S.J. NHC-catalysed aerobic aldehyde-esterifications with alcohols: No additives or cocatalysts required. Chem. Commun. 2013, 49, 6510-6512. [CrossRef] [PubMed] 
59. Nair, V.; Varghese, V.; Paul, R.R.; Jose, A.; Sinu, C.R.; Menon, R.S. NHC catalyzed transformation of aromatic aldehydes to acids by carbon dioxide: An unexpected reaction. Org. Lett. 2010, 12, 2653-2655. [CrossRef] [PubMed]

60. Gu, L.; Zhang, Y. Unexpected $\mathrm{CO}_{2}$ Splitting Reactions To Form CO with N-Heterocyclic Carbenes as Organocatalysts and Aromatic Aldehydes as Oxygen Acceptors. J. Am. Chem. Soc. 2010, 132, 914-915. [CrossRef] [PubMed]

61. Chiang, P.C.; Bode, J.W. On the role of $\mathrm{CO}_{2}$ in NHC-catalyzed oxidation of aldehydes. Org. Lett. 2011, 13, 2422-2425. [CrossRef] [PubMed]

62. Maki, B.E.; Chan, A.; Phillips, E.M.; Scheidt, K.A. Tandem oxidation of allylic and benzylic alcohols to esters catalyzed by $N$-heterocyclic carbenes. Org. Lett. 2007, 9, 371-374. [CrossRef] [PubMed]

63. Li, G.T.; Gu, Q.; You, S.L. Enantioselective annulation of enals with 2-naphthols by triazolium salts derived from L-phenylalanine. Chem. Sci. 2015, 6, 4273-4278. [CrossRef] [PubMed]

64. Kharasch, M.S.; Joshi, B.S. Reactions of Hindered Phenols. II. Base-Catalyzed Oxidations of Hindered Phenols. J. Org. Chem. 1957, 22, 1439-1443. [CrossRef]

65. Chen, Q.; Zhu, T.; Majhi, P.K.; Mou, C.; Chai, H.; Zhang, J.; Zhuo, S.; Chi, Y.R. Carbene-catalyzed enantioselective oxidative coupling of enals and di(hetero)arylmethanes. Chem. Sci. 2018. [CrossRef]

66. Liu, B.; Yan, J.; Huang, R.; Wang, W.; Jin, Z.; Zanoni, G.; Zheng, P.; Yang, S.; Chi, Y.R. Kinetic Resolution of 1,2-Diols via NHC-Catalyzed Site-Selective Esterification. Org. Lett. 2018, 20, 3447-3450. [CrossRef] [PubMed]

67. Zheng, C.; Liu, X.; Ma, C. Organocatalytic Direct N-Acylation of Amides with Aldehydes under Oxidative Conditions. J. Org. Chem. 2017, 82, 6940-6945. [CrossRef] [PubMed]

68. Wanner, B.; Mahatthananchai, J.; Bode, J.W. Enantioselective synthesis of dihydropyridinones via NHC-Catalyzed Aza-Claisen reaction. Org. Lett. 2011, 13, 5378-5381. [CrossRef] [PubMed]

69. Du, Y.; Wang, Y.; Li, X.; Shao, Y.; Li, G.; Webster, R.D.; Chi, Y.R. N-Heterocyclic Carbene Organocatalytic Reductive $\beta, \beta$-Coupling Reactions of Nitroalkenes via Radical Intermediates. Org. Lett. 2014. [CrossRef] [PubMed]

70. Chen, X.Y.; Chen, K.Q.; Sun, D.Q.; Ye, S. N-Heterocyclic carbene-catalyzed oxidative [3 + 2] annulation of dioxindoles and enals: Cross coupling of homoenolate and enolate. Chem. Sci. 2017, 8, 1936-1941. [CrossRef] [PubMed]

71. Song, Z.Y.; Chen, K.Q.; Chen, X.Y.; Ye, S. Diastereo- and Enantioselective Synthesis of Spirooxindoles with Contiguous Tetrasubstituted Stereocenters via Catalytic Coupling of Two Tertiary Radicals. J. Org. Chem. 2018, 83, 2966-2970. [CrossRef] [PubMed]

72. White, N.A.; Rovis, T. Enantioselective $N$-heterocyclic carbene-catalyzed $\beta$-hydroxylation of enals using nitroarenes: An atom transfer reaction that proceeds via single electron transfer. J. Am. Chem. Soc. 2014, 136, 14674-14677. [CrossRef] [PubMed]

73. Zhang, Y.; Du, Y.; Huang, Z.; Xu, J.; Wu, X.; Wang, Y.; Wang, M.; Yang, S.; Webster, R.D.; Chi, Y.R. $N$-heterocyclic carbene-catalyzed radical reactions for highly enantioselective $\beta$-hydroxylation of enals. J. Am. Chem. Soc. 2015, 137, 2416-2419. [CrossRef] [PubMed]

74. White, N.A.; Rovis, T. Oxidatively initiated NHC-catalyzed enantioselective synthesis of 3,4-disubstituted cyclopentanones from enals. J. Am. Chem. Soc. 2015, 137, 10112-10115. [CrossRef] [PubMed]

75. Zhao, K.; Enders, D. Merging N-Heterocyclic Carbene Catalysis and Single Electron Transfer: A New Strategy for Asymmetric Transformations. Angew. Chem. Int. Ed. 2017, 56, 3754-3756. [CrossRef] [PubMed]

76. Liu, Y.K.; Li, R.; Yue, L.; Li, B.J.; Chen, Y.C.; Wu, Y.; Ding, L.S. Unexpected ring-opening reactions of aziridines with aldehydes catalyzed by nucleophilic carbenes under aerobic conditions. Org. Lett. 2006, 8, 1521-1524. [CrossRef] [PubMed]

77. Delany, E.G.; Fagan, C.L.; Gundala, S.; Zeitler, K.; Connon, S.J. Aerobic oxidation of NHC-catalysed aldehyde esterifications with alcohols: Benzoin, not the Breslow intermediate, undergoes oxidation. Chem. Commun. 2013, 49, 6513-6515. [CrossRef] [PubMed]

78. Reddi, R.N.; Prasad, P.K.; Sudalai, A. N-Heterocyclic Carbene Catalyzed Oxidative Coupling of Alkenes / $\alpha$-Bromoacetophenones with Aldehydes: A Facile Entry to $\alpha, \beta$-Epoxy Ketones. Angew. Chem. Int. Ed. 2015, 54, 14150-14153. [CrossRef] [PubMed] 
79. Nakanishi, I.; Itoh, S.; Fukuzumi, S. Electron-transfer properties of active aldehydes of thiamin coenzyme models, and mechanism of formation of the reactive intermediates. Chem. A Eur. J. 1999, 5, 2810-2818. [CrossRef]

80. Finney, E.E.; Ogawa, K.A.; Boydston, A.J. Organocatalyzed Anodic Oxidation of Aldehydes. J. Am. Chem. Soc. 2012, 134, 12374-12377. [CrossRef] [PubMed]

81. Green, R.A.; Pletcher, D.; Leach, S.G.; Brown, R.C.D. N-Heterocyclic Carbene-Mediated Oxidative Electrosynthesis of Esters in a Microflow Cell. Org. Lett. 2015, 17, 3290-3293. [CrossRef] [PubMed]

82. Green, R.A.; Pletcher, D.; Leach, S.G.; Brown, R.C.D. N-Heterocyclic Carbene-Mediated Microfluidic Oxidative Electrosynthesis of Amides from Aldehydes. Org. Lett. 2016, 18, 1198-1201. [CrossRef] [PubMed]

83. Ogawa, K.A.; Boydston, A.J. Organocatalyzed anodic oxidation of aldehydes to thioesters. Org. Lett. 2014, 16, 1928-1931. [CrossRef] [PubMed]

(C) 2018 by the authors. Licensee MDPI, Basel, Switzerland. This article is an open access article distributed under the terms and conditions of the Creative Commons Attribution (CC BY) license (http://creativecommons.org/licenses/by/4.0/). 